\title{
Phytochemical, Pharmacognostic and Microscopic Analyses of the Leaves of Clerodendrum polycephalumBaker
}

\author{
Henry O. Egharevba, Jemilat A. Ibrahim*, Grace Ezeh \\ Department of Medicinal Plant Research and Traditional Medicine [MPR\&TM], National Institute for Pharmaceutical Research and Development \\ [NIPRD], Idu - Abuja. Department of Plant Science Modibbo Adama University of Technology, Yola, Adamawa state, Nigeria.
}

\begin{tabular}{|c|c|}
\hline ARTICLE INFO & ABSTRACT \\
\hline Article history: & \multirow{10}{*}{$\begin{array}{l}\text { Phytochemical, pharmarcognostic and microscopy analysis were carried out on the leaves of Clerodendrum } \\
\text { polycephalum Baker in order to determine the secondary metabolites present in the plant and the } \\
\text { pharmacognostic parameters and microscopic structures of the leaf of the plant. The phytochemical screening } \\
\text { indicated the presence of carbohydrate, reducing sugar, tannins, saponins, flavonoids, resins, balsams, alkaloid } \\
\text { and phlobatannins and the absence of monosaccharide, combined reducing sugar, pentose sugar, ketoses, cardiac } \\
\text { glycosides, sterols, flavonoids aglycone and anthraquinone. The pharmacognostic analysis for moisture content } \\
\text { and extractive values showed moisture content of } 7.4 \% \text {, and alcohol and water extractive value of } 23.00 \% \text { and } \\
22.67 \% \text { respectively. Microscopic studies revealed the presence of anomocytic Stomata on the lower surface and } \\
\text { absence of it on the upper surface. The thin layer chromatographic study showed } 5 \text { spots for the hexane extract, } 4 \\
\text { spots for ethyl acetate extract, while the methanol extract gave } 3 \text { spots. The information obtained would be useful } \\
\text { for the authentication of the plant leaf samples, and in development of monograph for the plant. }\end{array}$} \\
\hline Received on: 15/04/2015 & \\
\hline Revised on: $11 / 05 / 2015$ & \\
\hline Accepted on: $29 / 05 / 2015$ & \\
\hline Available online: 27/07/2015 & \\
\hline Key words: & \\
\hline Clerodendrum polycephalum, & \\
\hline Phytochemistry, & \\
\hline Pharmacognosy, microscopy, & \\
\hline TLC & \\
\hline
\end{tabular}

\section{INTRODUCTION}

Clerodendrum polycephalum Baker is a species of flowering plant belonging to the family Verbenaceae. It is an erect or scandent shrub or lianas, or small tree of about $4 \mathrm{~m}$ tall, found in savannah and close jungle. Leaves are decussate (whorled), sepals usually connate, lobes are unequal (Briquet, 1895). It is native to tropical and warm temperate regions of the world with most of the species occurring in tropical Africa, South Asia and a few extending north into the temperate Zone in eastern Asia, they are also found in Cameroun, Ghana, Sierra Leone, and Guinea to Southern Nigeria (Steane et al., 1999; Burkill, 2000; Mabberley, 2008). C. polycephalum is important medicinally. In Ivory Coast, the leaf-sap of the plant is used to wash the face of persons subjected to fainting, giddiness and attacks of epilepsy (Adegoke, 1968). In Nigeria, the Yorubas commonly refer to it as 'aporo' which said to mean, 'it kills pain', and it is used as antidotes for venomous stings and bites.

* Corresponding Author

Jemilat A. Ibrahim, Department of Medicinal Plant Research and

Traditional Medicine [MPR\&TM], National Institute for Pharmaceutical

Research and Development [NIPRD], Idu - Abuja

Email: sadiqoyene@yahoo.com
It is also used as pain killer and medicine for the treatment of paralysis, epilepsy, convulsion, spams etc., (Dalziel, 1937). In spite of the ethnomedicinal importance of this plant, very little information is available on the plant in literature.

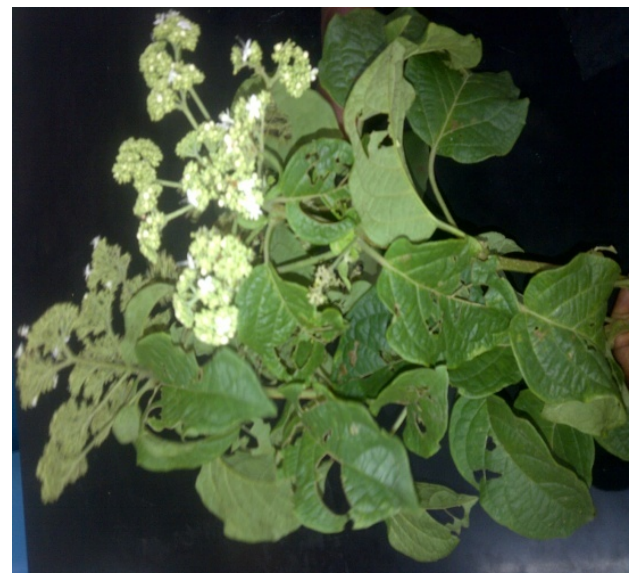

Fig. 1: Leaves of Clerodenron polycephalum

The aim of this research work is to determine the phytochemical profile, pharmacognostic parameter and microscopy of the leaves for easy identification and monograph development. 


\section{MATERIALS AND METHODS}

All reagents used were Analytical grade and sourced from Zayo-Sigma Nigeria Limited.

\section{Collection of Plants}

Clerodendrum polycephalum leaves were collected from a near-by fallow land around Idu on the $1^{\text {st }}$ July, 2013, and identified in the herbarium of the National Institute for Pharmaceutical Research and Development Abuja, Nigeria. The fresh leaves were air-dried indoors for two weeks and pulverised using a mortar and pestle. The powdered samples were stored in air tight container for the phytochemical and pharmacognostic analyses.

\section{Determination of Physicochemical constants}

Determinations of the moisture content and extractive values of the powdered leaves were carried out according to standard methods (Sofowora, 2008; Evans, 2002; African pharmacopeia, 1986).

\section{Phytochemical Analysis}

The powdered leaves were screened for the presence of secondary metabolites such as carbohydrate, monosaccharide, reducing sugar, tannins, combined reducing sugar, saponins, flavonoids, resins, balsams, cardiac glycosides, ketoses, pentose sugar, sterol, alkaloid and phlobatannins. The phytochemical screening was carried out following standard method (Sofowora, 2008; Evans, 2002).

\section{Thin-layer chromatography}

Thin layer chromatography (TLC) of the extracts was carried out to determine the number of components present in each extract. TLC plates pre-coated with K5 silica gel were used. $1 \mathrm{mg} / \mathrm{ml}$ solutions of the extracts were spotted using capillary tubes. Hexane and ethyl acetate extracts were developed in solvent system of hexane and ethyl acetate, ratio 9:1. The methanol extract was developed in solvent system of ethyl acetate and methanol in ratio $3: 2$.

The plates were observed for spots after spraying with dilute sulphuric acid and the retardation factor $\left(\mathrm{R}_{\mathrm{f}}\right)$ for each spot was determined (Harborne, 1998).

\section{Microscopic examination}

Leaves of Clerodendrum polycephalum were cut at the median portion. Some of it was soaked in concentrated nitric acid and left for 48hours. The appearance of air bubbles showed that the epidermis was ready to be separated. The samples were then transferred to petri dishes containing water and with the use of fine forceps and dissecting needle; the upper and lower epidermis was separated. Each set was stained with saffranin and Sudan IV and mounted on slides in glycerol. The edges of the cover slip was sealed with nail vanish to prevent dehydration.

\section{RESULTS AND DISCUSSION}

The result of the phytochemical screening as shown in Table 1 revealed the presence of carbohydrate, reducing sugar, Tannins, Saponins, Flavonoids, resins, balsams, alkaloid and phlobatannins. Cardiac glycosides, sterols and anthraquinones were however not detected. The presence of these classes of metabolite may be responsible for the observed effect in ethnomedicine (Burkil, 2000).

Table 1: Result of phytochemical analysis of the leaves of Clerodendrum polycephalum.

\begin{tabular}{|c|c|}
\hline Secondary Metabolite & Inference \\
\hline Carbohydrate & + \\
\hline Monosaccharide & _ \\
\hline Reducing Sugar & + \\
\hline Combined Reducing Sugar & _ \\
\hline Pentose Sugar & - \\
\hline Tannins & + \\
\hline Saponins & + \\
\hline Cardiac glycosides & _ \\
\hline Flavonoids & + \\
\hline Sterols & - \\
\hline Resins & + \\
\hline Balsams & + \\
\hline Alkaloids & + \\
\hline Phlobatannins & + \\
\hline Anthraquinone & 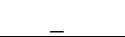 \\
\hline
\end{tabular}

For instance tannins have astringent properties and are used to treat tonsillitis and skin eruption. Tannin has been administered internally to check diarrhoea and intestinal bleeding (Thorington Jr. and Ferrell, 2006). Saponins are used to treat yeast and fungal infections (Roa et al., 1995).

Flavonoid has been demonstrated to be relevant in defense against pathogenic infection, regulation of cellular oxidation and oxidative stress disorder such as inflammatory and tumor diseases (Evans, 2002; Shrivastava and Patel, 2007; Kunle and Egharevba, 2013). Resins have been used for treatment of inflammatory conditions as well as in cancerous diseases (Evans, 2002). The pharmacological activity of plants alkaloid have long been established, for instance quinine, piperine, etc., (Okwute and Egharevba, 2013). Therefore, the presence of these metabolites in this plant may support their uses in treatment of various ailments traditionally.

Table 2: Result of the physicochemical parameters of the leaves of Clerodendron polycephalum.

\begin{tabular}{ll}
\hline \multicolumn{1}{c}{ Parameter } & \% Value \\
\hline Moisture Content & 7.40 \\
Alcohol-extractive Value & 23.00 \\
Water-extractive Value & 22.67 \\
\hline
\end{tabular}

Table 2 shows the results of the physicochemical evaluation of the leaf powder. The alcohol extractive value $(23.00 \%)$ was not significantly different from the water extractive value $(22.67 \%)$, suggesting that both solvents may be equally as good for extractions. The value of the moisture content of the leaf $(7.40 \%)$ was within the official ranges of $8-14.5 \%$ for vegetable 
drugs (African pharmacopeia, 1989). This implied that the plant does not retain much water to support microbial attack after drying and when stored under good condition. This may have good implication on the shelf-life of the well-packaged crude vegetable drug.

\section{Thin layer chromatography (TLC) of the extracts}

The hexane extract gave 5 spots; ethyl acetate extract gave 4 spots while methanol extract gave 3 spots (Table 3 ).

\section{Microscopic Examination of Epidermal Layer}

The upper epidermal layer of $C$. polycephalum (Figure 2), showed irregular shaped epidermal cells, no stomata and the cell surrounding the trichomes base were peculiar, multicellular trichomes types and trichomes base were observed. The lower epidermal surface of $C$. polycephalum (Figure 3) was characterized by abundant anomocytic stomata, irregular shaped cells, multicellular trichomes, trichomes were abundant towards the vein, cells surrounding the stomata were striated, epidermals cell wall undulate than the epidermal cells on the upper surface. The presence of trichomes indicated that the leaves are nonglabrous (rough and with hairs) at the upper surface, while the presence of stomata on the lower surface indicates that gaseous exchange take place through the lower surface. The multicellular trichomes and irregular shaped epidermal cells are diagnostic feature for the plant.

Table 3: Results of TLC of the extracts of the leaves of Clerodendron polycephalum.

\begin{tabular}{|c|c|c|c|}
\hline Spots & Hexane extract $\left(R_{f}\right)$ & Ethyl acetate extract $\left(R_{f}\right)$ & Methanol extract $\left(\mathbf{R}_{\mathrm{f}}\right)$ \\
\hline 1 & 0.92 & 0.94 & 0.48 \\
\hline 2 & 0.30 & 0.86 & 0.22 \\
\hline 3 & 0.20 & 0.61 & 0.06 \\
\hline 4 & 0.13 & 0.38 & \\
\hline 5 & 0.08 & & \\
\hline
\end{tabular}

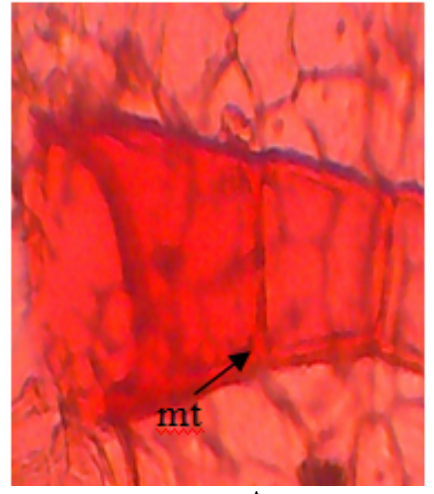

A Adaxial (x400)

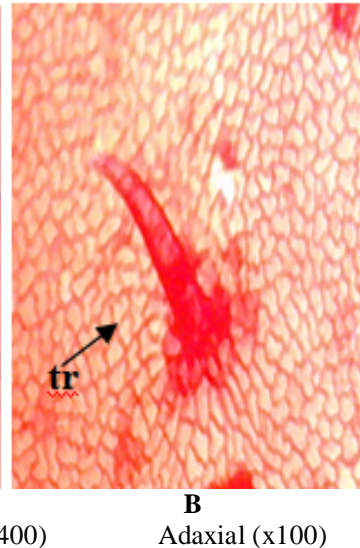

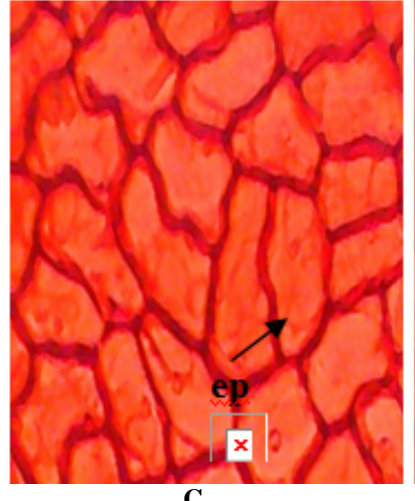

Adaxial $(\mathrm{x} 400)$

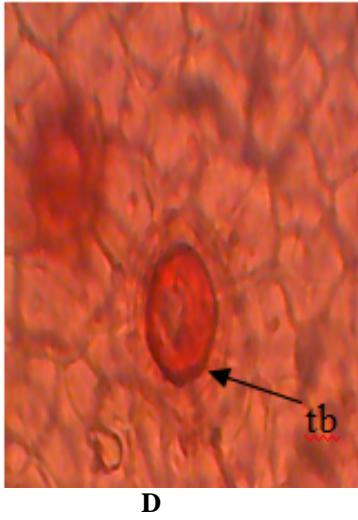

Adaxial (x400)

Fig. 1: Photomicrographs of Adaxial Epidermal layers of Clerodendrum polycephalum.

Key : A - epidermal cells showing multicellular trichome; B - showing trichome at lower magnification; C - Irregular shaped epidermal cells; D - showing trichome base; Mt - multicellular trichome, $\mathbf{T r}$ - Trichome, ep - epidermal cells, $\mathbf{T b}$ - Trichome base.

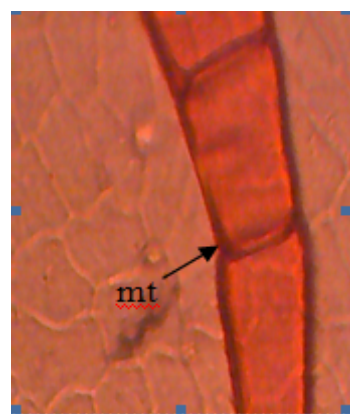

A

Abaxial (x400)

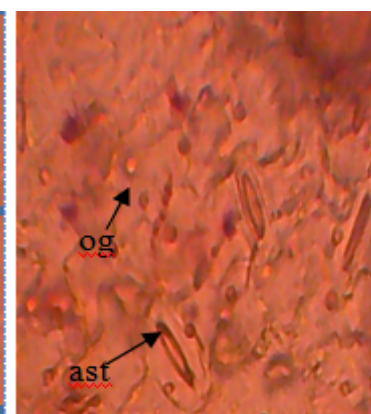

B

Abaxial (x100)

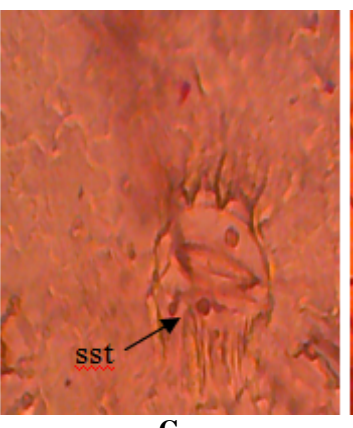

Abaxial (x400)

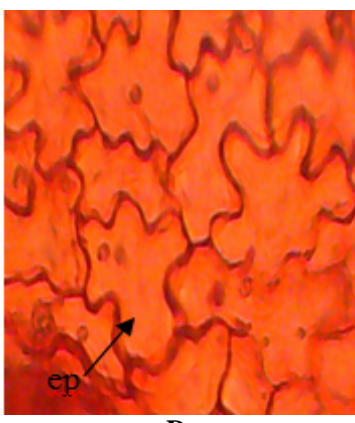

D

Abaxial (x400)

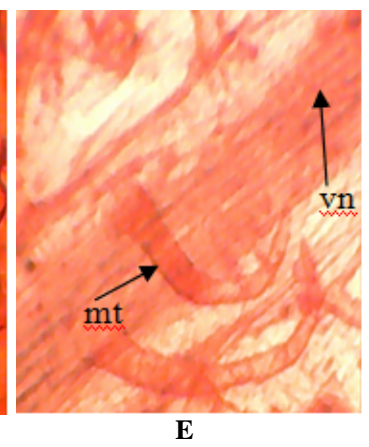

Abaxial x400

Fig. 2: Photomicrographs of Abaxial Epidermal layers of leaves of Clerodendron polycephalum

Key: A- Abaxial epidermal cells showing multicellular trichomes; B - showing abundant stomata, C - cells surrounding the stomata are striated, D - Irregular shaped cells, E - multicellular trichomes abundant on the veins; $\mathbf{m t}$ is multicellular trichomes, abs - abundant stomata, sst - straited stomata, ep - epidermal cells, vn - veins 


\section{CONCLUSION}

The leaf samples of $C$. polycephalum were rich in secondary metabolites and therefore could be potential sources of phytomedicines and leads for new drugs. The information presented here will be useful in standardization and monograph development on the plant.

\section{ACKNOWLEDGMENT}

The authors wish to acknowledge Ibrahim Muazzam Wudil for his assistance in the collection of plant samples.

\section{REFERENCES}

Adegoke EA, Akinsanya A, Naqui SHZ. Studies of Nigerian Medicinal Plants 1. A preliminary survey of plant Alkaloid; J. West Africa Sci. Assoc., 1968, 13: 13-33.

African Pharmacopoeia. 2001. General Methods of Analysis. Lagos :(OAU/STRC) 143

Barkan A. Acromegaly diagnosis and therapy. Endocrinol. Metab. Clin. North Am., 1989, 277-310.

Briquet JI. 1895. Clerodendrum. In: Verbenaceae In: Die Natürlichen Pflanzenfamilien volume IV, part 3a. Verlag von Wilhelm Engelmann: Leipzig, Germany. 174-176

Burkil HM. 2000. The useful plants of West Tropical Africa. $2^{\text {nd }}$

Edition. Volume 5, Royal Botanic Gardens, Kew, United Kingdom. 686

Dalziel JM. 1937. The useful plants of West Tropical Africa

(ed.1): Crown Agents for the Colonies, London. 454

Evans WC.2002. Trease and Evans Pharmacognosy, $15^{\text {th }}$ Ed. London: W.B. Sanders. 183-393.
Harborne JB. 1998. Phytochemical methods. A guide to modern techniques of plant analysis. $3^{\text {rd }}$ ed. Chapman and Hall Int. Ed. NY. 11-12, 44, 291-293.

Kunle OF, Egharevba HO. Chemical constituents and biological activity of medicinal plants used for the management of sickle cell disease - A Review. JMPR, 2013; 7(48): 3452-3476.

Mabberley D. 2008. Mabberley's plant-book. A portable dictionary of plants, their classifications, and uses, 3rd edn. Cambridge: Cambridge University Press.

Okwute SK, Egharevba HO. Piperine-Type Amides: Review of the Chemical and Biological Characteristics. Int'l J. Chem., 2013; 5(3): 99-122.

Roa RR, Babu RM, Rao MRV. Saponins as anti-carcinogens. The J. Nutr. 1995; 125: 717-724.

Shrivastava N, Patel T. Clerodendrum and Heathcare: An Overview. Medicinal and Aromatic Plant Science and Biotechnology 2007;1(1): 142-150

Sofowora A. 2008. Medicinal Plants and Traditional Medicine in Africa. $3^{\text {rd }}$ Ed. Spectrum Book Limited, Ibadan, Nigeria. 199-204.

Steane DA, Scotland RW, Mabberley DJ, Olmstead RG. Molecular systematics of Clerodendrum (Lamiaceae): its sequences and total evidence. American Journal of Botany 1999; 86: 98-107

Thorington Jr. RW, Ferrell KE. 2006. The animal answer guides. Baltimore: Johns Hopkins University press, New York 208.

\section{How to cite this article:}

Henry O. Egharevba, Jemilat A. Ibrahim, Grace Ezeh. Phytochemical, Pharmacognostic and Microscopic Analyses of the Leaves of Clerodendrum Polycephalum Baker. J App Pharm Sci, 2015; 5 (07): 060-063. 